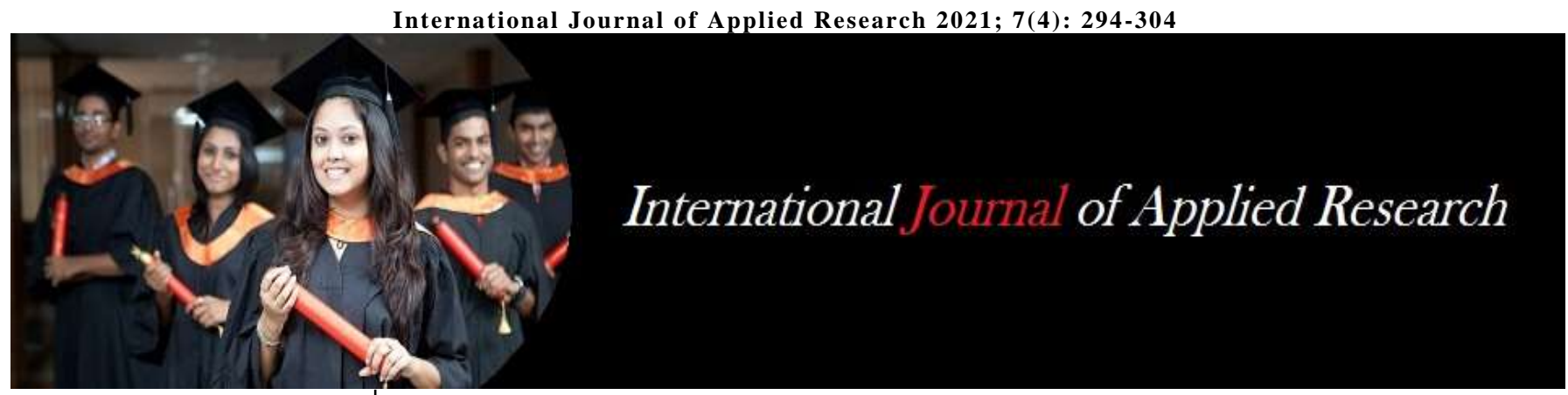

ISSN Print: 2394-7500 ISSN Online: 2394-5869 Impact Factor: 8.4 IJAR 2021; 7(4): 294-304 www.allresearchjournal.com Received: 07-02-2021 Accepted: 11-03-2021

Dr. Manjula Wanninayaka Graduate School of Sociology, Kansai University, Japan
Corresponding Author: Dr. Manjula Wanninayaka Graduate School of Sociology, Kansai University, Japan

\section{Relations between production team satisfaction and team characteristics in the manufacturing organization in Sri Lanka}

\section{Dr. Manjula Wanninayaka}

DOI: https://doi.org/10.22271/allresearch.2021.v7.i4e.8506

\section{Abstract}

The study investigated the team satisfaction by constructing a model which is including defining characteristics of a work team: mutual support, a common goal, multi-skills and task interdependence. The structural relationships between all variables were evaluated using quantitative data which was obtained from 190 shop-floor level workers in the manufacturing organization in Sri Lanka. The study verified that a common goal, multi-skills and task interdependence indirectly affect team satisfaction through the mediation of mutual support. That means, a common goal, multi-skills and task interdependence strengthen mutual support, further leading to enhance the team members' satisfaction. Finally, the study results contribute to the understanding of the rudimentary process in the relation between characteristics of the team and team satisfaction.

\section{Keywords: Characteristics of work team, team satisfaction, production workers, Sri Lanka}

\section{Introduction}

This paper examines the relations between production team satisfaction and work team characteristics of the manufacturing organization in Sri Lanka. Team satisfaction is considered as a factor which measures the effectiveness of teams in work organizations (Breuer, Hüffmeier \& Hertel, 2016; Cohen \& Bailey, 1997) ${ }^{[7,14]}$. Team satisfaction elaborates the members' satisfaction in the team (Barczak \& Wilemon, 2001) ${ }^{[4]}$ and concerns the overall satisfaction regarding work (Strubler \& York, 2007) ${ }^{[74]}$, colleagues and their way of work in the team (Van Der Vegt \& Van De Vliert, 2000) ${ }^{[81]}$.

In the preceding theories, team characteristics have been identified as the determinates of team satisfaction (Mayfield, Tombaugh \& Lee, 2016; Gittel, 2011; Barczak \& Wilemon, 2001; Van de Vegt, Emans \& Van de Vliert, 2001; Van Der Vegt \& Van De Vliert, 2000;

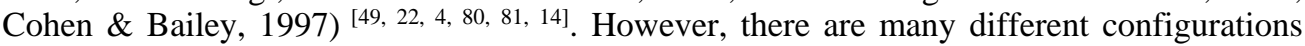
(Mathieu, Maynard, Rapp \& Gilson, 2008) ${ }^{[48]}$. For instance, Barczak and Wilemon (2001) ${ }^{[4]}$ have pointed out that the perception of the team's goal, supportive activities and multi-skills capability improve the team members' satisfaction, by using the non-numerical way. Mayfield, Tombaugh and Lee (2016) ${ }^{[49]}$ and Cohen and Bailey (1997) ${ }^{[14]}$ have discussed about the effectiveness of teamwork considering satisfaction and task interdependence. Further, Van de Vegt, Emans and Van de Vliert (2001) ${ }^{[80]}$ and Van Der Vegt and Van De Vliert (2000) ${ }^{[81]}$ have proved that there is a relationship between team satisfaction, team members' awareness of team's goal and task interdependence, statistically. Based on the previous literature, the above components: multi-skills, mutual support, a common goal and task interdependence are able to be recognized as the defining characteristics of work teams, particularly which are in the manufacturing work organizations (Kozlowski \& Bel, 2013; Morita, 2008; Katzenbach \& Smith, 1995; Wellins, Byham, \& Wilson, 1991; Trist, Higgin, Murray \& Pollock, 1987) ${ }^{[39,52,86,78]}$, in the management perspective since they are controlled by the team-based management practices (Bratton \& Gold, 2017; Kirkman \& Rosen, 1999) ${ }^{[6}$, 37], as discussed in the subsequent theoretical review. Despite the above findings regarding team satisfaction, little is known about how all these constructs relate to team satisfaction. It means that, even though the role of team characteristics on team satisfaction has been previously investigated by using different configurations, the study tended to combine four dimensions of team into a single model. 
Therefore, this empirical study evaluates the relationship between team characteristics and team satisfaction considering all predictable relations. The study concerns the Sri Lankan context to carry out the investigation because, even recent research has begun to discuss teamwork practises in the Sri Lankan context, (Morita \& Wanninayaka, 2016; Wanninayaka, 2015; Lanarolle and Rathnayake, 2014; Pathirage, Jayawardena \& Rajapaksha, 2012; Jayawardana \& O'Donnell, 2009) [53, 84, 42, 61, 32, 52], there is a lack of research which examines what are the determining factors of team satisfaction. In addition, the number of companies in Sri Lanka that have introduced Toyota Production System (TPS) as a method of reorganization of workplaces is increasing (Kulasooriya \& Chalapathi, 2014: Silva, Perera \& Samarasinghe, 2011; Wickramasinghe \& Wickramasinghe, 2011) [40, 70, 87]. Further, in order to promote the TPS in Sri Lanka, the institute of Lean Management (Pvt) Ltd. was established in 2009 as a consulting organization. As a result, it can be assumed that the interest in teamwork will gradually increase even in Sri Lanka since, "teamwork is everything in the TPS" (Ohno, 1978, p.44) [56] and "the work team that emerges as the heart of the lean factory" (Womack, Jones \& Roos, 1990, p.99) ${ }^{[88]}$.

Therefore, this evidence creates the opportunity to discuss team relating theories in the Sri Lankan context. Depending on these discussions, on the one hand, work organizations are able to get an idea about how they can satisfy their employees and what team factors affect employees' satisfaction in the team. On the other hand, the existing literature regarding team satisfaction and team characteristics can be expended to evaluate the situation in Sri Lanka, as another country level.

Accordingly, in this paper, the relations between team satisfaction and team characteristics of the manufacturing organization in Sri Lanka are evaluated based on the existing theories, using statistical analyses.

\section{Literature Review}

In the literature, there is not a unique definition for the team (Mathieu et al., 2008) because scholars have defined the team considering their study purposes. However, the team definition which is developed by Katzenbach and Smith (1995), that is, "a team is a small number of people with complementary skills who are committed to a common purpose, performance goals, and approach for which they hold themselves mutually accountable" (p.45) can be identified as a representative definition of the team literature and academic discussions of a work team because the features of the definition have been taken into account as the necessities of the team by many other scholars (Kozlowski\& Bel, 2013; Morita, 2008; Procter \& Mueller, 2000; Wellins, et al., 1991; Trist, et al., 1987) [39, 52, 63, 86, 78], too. In sum, these necessities can be presented as multi-skills, a common goal, task interdependence and mutual support. Before the main purpose of the study, that is, to evaluate the relationship between team satisfaction and team characteristics is discussed, it may be useful to clarify why the above components become the necessities of a work team.

In the conventional work organizations, people worked to achieve the goal which was set individually (Bratton \& Gold, 2017; Wellins et al., 1991) ${ }^{[6,86]}$ and the one-man onejob principle is used to set up the individual goal (Morita, 2008; Okubayasi, 2002) [52, 57]. Conversely, in the contemporary work organizations, team-based work organizations, goal(s) is set on the team basis by using the one-team one-task principle and people work having a perception of team's goal(s) (Owens \& Hekman, 2016; Salas, Shuffler, Thayer, Bedwell \& Lazzara, 2015; Morita, 2008; 2001; Katzenbach \& Smith, 1995) ${ }^{[67,59,52,60]}$. And, team members are jointly responsible for the achievement of the team's goals (Suzuki, 2013; 2011; Morita, 2008) ${ }^{[76,75,}$ 52]. The previous research has used different terms such as collective goals (Owens \& Hekman, 2016) ${ }^{[59]}$, shared goal and a common goal (Salas et al., 2015) ${ }^{[67]}$, common goal(s) (Kozlowski\& Bel, 2013; Morita, 2008) ${ }^{[39,52]}$ and a common purpose and performance goals (Katzenbach \& Smith, 1995) to describe the team-based goal(s) and team members' awareness on it.

Further, Gallie, Zhou, Felstead and Green (2012) ${ }^{[21]}$, Morita (2008) ${ }^{[52]}$, Procter and Mueller (2000) ${ }^{[63]}$ and Klein (1994) ${ }^{[38]}$ have explained that the workers who work in the team should acquire various kinds of task-related knowledge and skills to perform different sorts of work. Trist (1981) [77] suggests functional redundancy for the team-based work practices and training the workers on different kinds of task was identified as an inevitable requirement to deal with it (Morita, 2008; Trist, 1981) ${ }^{[52,77]}$. Therefore, most of the preceding research has emphasized the importance of the multi-skills development for the team (Gallie, Zhou, Felstead \& Green, 2012; Morita, 2008; 2001; Mair, 2007; Procter \& Mueller, 2000; Katzenbach \& Smith, 1995; Klein, 1994; Wellins et al., 1991) [21, 60, 52, 63, 38, 86]. Hence, teambased organizations arrange various kinds of training facilities to improve employees' task-related skills. These training facilities are planned in two ways: On-the Job Training (OJT) methods, particularly job rotation, is very common and Off-the-Job Training (Off-JT) methods such as a training school at the factory premises (Greenwood \& Randle, 2007) ${ }^{[24]}$.

Moreover, task interdependence has been identified as a necessary condition for a team by the previous theoretical discussions of team (Ullah \& Park, 2013; Kozlowski \& Bell, 2013; Suzuki, 2013; 2011; Cohen \& Bailey, 1997; Saavedra, Earley \& Van Dyne, 1993) [39, 76, 75, 14], too. Courtright, Thurgood, Stewart and Pierotti (2015) ${ }^{[16]}$ have defined task interdependence as "the degree to which task work is designed so that members depend upon one another for access to critical resources and create work flows that require coordinated action" (p.4). Suzuki $(2013 ; 2011){ }^{[76,75]}$ argues that task interdependence is able to be distinguished as objective task interdependence and subjective task interdependence. On the one hand, the way of arrangement of the work flow, that is work designing, decides the objective task interdependence of the team (Kumar, van Fenema \& Von Glinow, 2009; Morgeson \& Humphrey, 2008; Hertel, Konradt \& Orlikowski, 2004) ${ }^{[41,51,26]}$. On the other hand, worker's sense of task interdependence decides the subjective task interdependence (Suzuki, 2013; 2011; Somech, Desivilya \& Lidogoster, 2009; Van der Vegt \& Van de Vliert, 2005; Van der Vegt \& Janssen, 2003; Van de Vegt et al., 2001; Kiggundu, 1983) ${ }^{[76,72,83,80,36]}$ and degree of such task interdependence can be varied person to person (Van Der Vegt \& Van De Vliert, 2000) ${ }^{[81] . ~ T y p i c a l l y, ~}$ employees' awareness of dependency of work, information, ideas and other resources (Saavedra et al., 1993) and coordination and collaboration need (Courtright, Thurgood, Stewart \& Pierotti, 2015; Van der Vegt \& Janssen, 2003) ${ }^{[16,}$ 
${ }^{82}$ is concerned in the subjective task interdependence.

Most researchers have concluded that supporting each other is an indispensable factor for a team in the behavioural level (Salas et al., 2015; Hüffmeier \& Hertel, 2011; Morita, 2008) $[67,29,52]$. Therefore, a supportive work practice is identified as the heart of the team since "it makes the team truly operate as more than the sum of its parts" (McIntyre \& Salas, 1995, p.26) ${ }^{[50]}$. These supports consist of both affective supports like emotional and psychological assistance: listening sympathy and cheering fellow workers (Hüffmeier \& Hertel, 2011; Fenlason \& Beehr, 1994) ${ }^{[29,18]}$ and task-related support (Hüffmeier \& Hertel, 2011) [29] such as behavioural task support and information related task support: physical and knowledge assistance to fulfil other's job (Fenlason \& Beehr, 1994) ${ }^{[18]}$.

Accordingly, having a common goal and objective task interdependence is able to be identified as work level features and team member's perception of a common goal, having various kinds of skills and subjective task interdependence in the team can be recognized as worker level factors. And mutual support is a behavioural level (working level) characteristic.

\section{Team Satisfaction and Characteristics of Team}

As mentioned in the beginning, previous research has reported that characteristics of the team create the effect of team satisfaction. Therefore, how team factors influence the team satisfaction is reviewed through this section.

Lunenburg (2011) ${ }^{[45]}$, Stark and Bierly III (2009) ${ }^{[73]}$, Van de Vliert et al. (2001) ${ }^{[80]}$ and Champion, Papper and Medsher (1996) ${ }^{[10]}$ reported that the existence of team members' awareness of a common goal improves team satisfaction. Stark and Bierly III (2009) ${ }^{[73]}$ and Champion et al. (1996) ${ }^{[10]}$ have insisted that having awareness of common goal shares responsibilities equally among team members and satisfaction is the result. Further, Costen and Salazar (2011) ${ }^{[15]}$ and Barczak and Wilemon (2001) ${ }^{[4]}$ say that having various kinds of skills is a vital driver for team satisfaction. Multi-skilled workers can be used to cover daily absenteeism (Morita, 2008; Allwood \& Lee, 2004) ${ }^{[52]}$ and it diminishes the negative effect of absenteeism such as lowering the productivity of the team. Maintaining the productivity could be a favourable condition to employees who work in the organization which uses performancebased evaluation such as team-based production incentives (Appelbaum, Bailey, Berg \& Kalleberg, 2000) ${ }^{[2]}$. Moreover, development of multi-skills provides chances to know new things and expands the existing capabilities of workers (Potnuru, Sahoo \& Sharma 2018; Klein, 1994) ${ }^{[62,38]}$. These expansions of competences through learning increase the worker's psychological need (Felstead, Gallie, Green \& Inanc, 2015) ${ }^{[17]}$. Also, this multi-skills factor distinguished team-based and conventional work organizations (Wellins et al., 1991) ${ }^{[86]}$. In other words, in the conventional work organizations, workers perform a narrowly defined job. Meanwhile, in the team-based work organizations, workers have to perform various jobs. Therefore, organizations which are based on teams carry out multi-skills development programs and as the result, it prevents monotonous and repetitive work situations (Ketchum \& Trist, 1992) ${ }^{[35]}$ and having such good work conditions enhances the psychological needs on the job, such as satisfaction (Neirotti, 2018; Sapada, Modding, Gani \& Nujum, 2018) ${ }^{[55,}$

${ }^{68]}$. Therefore, based on these advantages, it can be assumed that team satisfaction and multi-skills have a direct relationship. Also, Van de Vliert et al. (2001) ${ }^{[80]}$ and Van Der Vegt and Van De Vliert, (2000) ${ }^{[81]}$ have proved the direct relationship of subjective task interdependence and team satisfaction, statistically.

However, even antecedent research has suggested and proved a direct relationship between team satisfaction and team factors, but there are contrastive points of view, too. Particularly, Champion et al. (1996) ${ }^{[10]}$ have pointed out that a goal which has been established on a team basis has no direct relationship with team satisfaction. As well, Morris and Venkatesh (2010) ${ }^{[54]}$ have reported that there is not direct relationship between multi-skills and team satisfaction. In addition, Champion et al. (1996) ${ }^{[10]}$ and Champion, Medsker and Higgs (1993) ${ }^{[9]}$ have revealed that there is not a direct relationship between subjective task interdependence and team satisfaction. These explanations are agreeable, to some extent because, based on the literature of team, a common goal, multi-skills and task interdependence factors create an effect on the team satisfaction through the peer supports (mutual support) as follows.

When team members have a good understanding of team's goal, it intensifies the team members' collectiveness and friendliness (Weingart \& Weldon, 1991) ${ }^{[85]}$ and improves the willingness to help others (Gonzalez-Mulé, DeGeest, McCormick, Seong \& Brown, 2014) [23], more than individual goal setting and in turn, team members work together with cooperative work practices to accomplish their work task (Hu \& Liden, 2015; 2011; Chen, Tang \& Wang, 2009) $[28,27,12]$. By contrast, instead of team-based goal setting, individual-based goal settings are also able to be performed (Wong et al., 2009) ${ }^{[89]}$. It, however, strengthens competitiveness among team members and creates conflict situations in the team (Saavedra et al., 1993) ${ }^{[66] .}$

Further, understanding about each other's job is a very important task in the team since it helps to achieve their final target collectively. Particularly, in the team, each member's skills, knowledge level and work experience can be different. At this kind of situation, members who have less work experience or skills would seek help from their colleagues who have comparatively high work skills, knowledge and experience. Bamberger (2009) [3] has identified this kind of situation as the help-seeking behaviour. Then, multi-skilled workers can deal with this help need. In summary, we can say that multi-skills cultivate the mutual support at the team (George and Jones, 1997) ${ }^{[25]}$ although there is lack of research which has confirmed the relationship between multi-skills and mutual support, statistically. Moreover, literature suggests that task interdependence has the capability to foster the supportive activities in the team (Hu \& Liden, 2015; Hüffmeier \& Hertel, 2011; Somech, et al., 2008) [28, 29], too, since task interdependence enhances the collectivisms of workers (Ramamoorthy \& Flood, 2004) ${ }^{[65]}$, cohesiveness of team members (Chen et al., 2009) and interaction awareness of team members (Kumar et al., 2009; Somech et al., 2008) [41].

Accordingly, a common goal, multi-skills and task interdependence factors help to create the supportive work practices at the team. Having cooperative work practices create a smooth and favourable environment at the

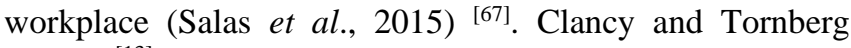
(2007) ${ }^{[13]}$ say, when any organization has established a 
mutually supportive work environment at a work team, it encourages the team member to identify another's assistance need promptly. Further, in the team, some members (e.g. newly recruited employee) can feel a high workload and stress. Those burdens can be eased thorough supportive behaviour (Hu \& Liden, 2015; Kalleberg, Nesheim, \& Olsen 2009) $[28,33]$. To sum up, support from other members creates the positive effect on the team satisfaction (Schreurs, Guenter, van Emmerik, Notelaers \& Schumacher, 2015; Champion, et al., 1996) ${ }^{[69,10]}$ with other characteristics of the team.

Based on the theoretical explanations, multi-skills, common goal and task interdependence depend on the way of management in an organization and mutual support takes place in the behavioural level of the team that is the working level. In other words, factors of multi-skills, a common goal and task interdependence can be considered as the antecedents of mutual support. And regarding team satisfaction, mutual support works as the intervening variable.

\section{Hypothesis and Conceptual Framework of the Study}

The theoretical explanations pointed out that direct and indirect relationship between team's characteristics: a common goal, multi-skills, task interdependence and mutual support, and team satisfaction. Considering all the above theoretical explanations, the following hypothesises can be developed.

H1: Common goal has a positive effect on mutual support

$\mathrm{H} 2$ : Multi-skills capability has a positive effect on mutual support

H3: Task Interdependence has a positive effect on mutual support

H4: Common goal(s) has a positive effect on team satisfaction

H5: Multi-skills capability has a positive effect on team satisfaction

H6: Task Interdependence has a positive effect on team satisfaction

H7: Mutual support has a positive effect on team satisfaction

$\mathrm{H} 4$

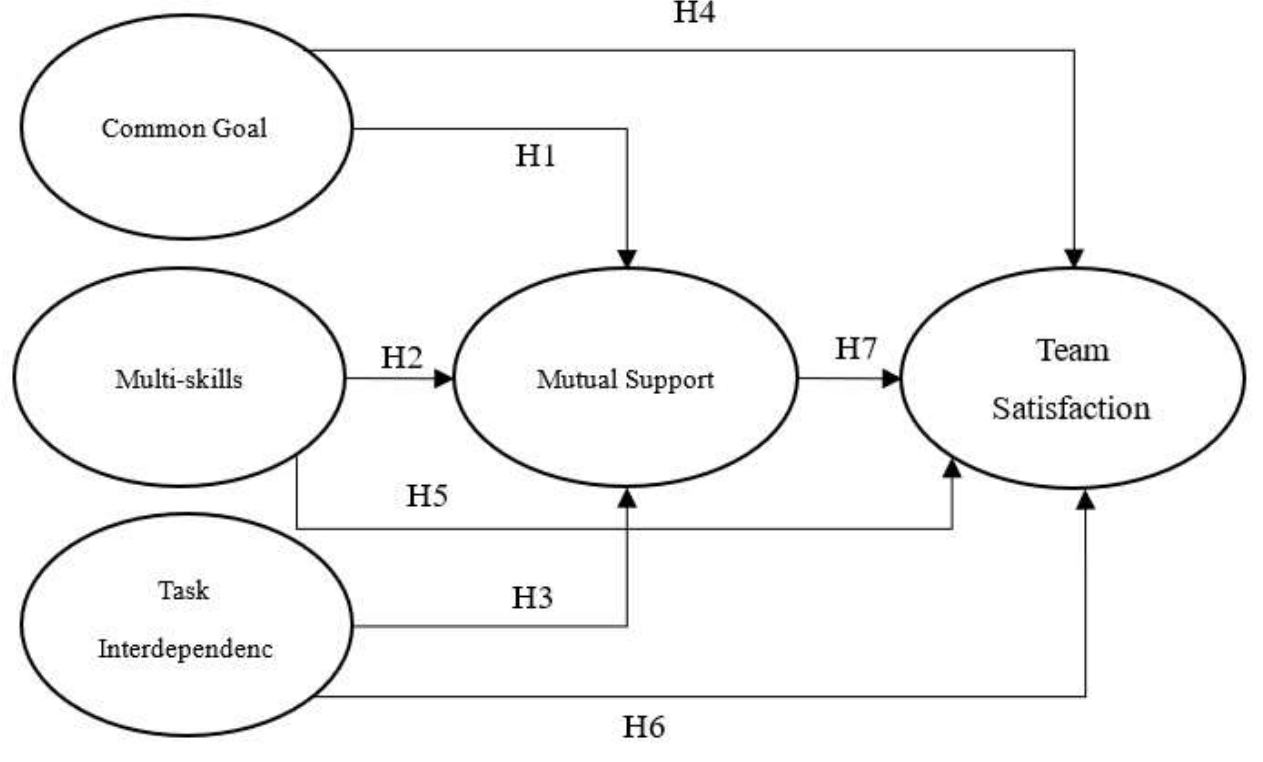

Source: Author's Design

Fig 1: Conceptual Framework of the Study

\section{Research Method \\ Sample and Sample Features}

The factory is a largely export-oriented porcelain manufacturing organization in Sri Lanka. The total workforce of the factory is 1034 and in which 850 workers are shop-floor level workers. According to the demographic data, more than three-fourths of production workers are women employees. The mean age level of the workers is 31 35 . The workers have more than 10 but less than 15 years work experience in the factory, on average. However, over 50 per cent of workers have more than 15 years work experience. Further, most of the workers have 13 years school education (77 per cent).

Shop-floor workers are selected as a target population for this study. The survey was carried out in March, 2019. As a sample, 240 shop-floor level workers were selected from 14 production teams which belonged to Casting, R/F, O/F, White ware inspection, Decoration and Decoration inspection departments. 190 usable responses (79 per cent of response rate) could be collected.
Before selecting the survey field, the existences of teambased goal setting, training and development process which wants to create multi-skilled workers and work designing which exhibits subjective task interdependence, were confirmed though the Human Resources department. Typically, each and every production team (production line) has a production target which should be accomplished collectively. Further, there is a multi-skills development program which has been established under "Monozukuri Concept" of the factory. According to an officer of the human resources department, Monozukuri Concept is a management program which considers cost reduction, improvement of safety and training of the employees. Every production department has to manage an Education and Training Skills Map on each employee skills development. Under this multi-skills development program, they hope to train their workers on at least three processes of the production flow. The factory provides 6 12 months training based on the multi-skill development program. OJT is used as the main training method and job rotations take place 
continuously based on the training plan. Even newly recruited employees are also trained on OJT. Also, work tasks have been arranged based on the flow-work principle. Each work station of the production process (forming, white-ware reduction firing, white-ware oxidation firing, biscuit inspection, white-ware inspection, decoration, decoration inspection etc.) fulfil the part of production. For example, in the glazing department, firstly, unloading biscuits from the hearth kiln and then removing dust which is on biscuit-wares by using compressors. Next, the glazing task is performed and finally, glazed biscuits are loaded to carts for firing them. Outputs of the glazing department, that is, white-wares are the inputs of the white-ware inspection department. Some tasks in the production station have been arranged as a moving assembly line using the belt system.

\section{Measures}

Employee's perception of a common goal (Common goal), employee's multi-skills capability (multi-skills), subjective task interdependence (task interdependence), employee's supportive behaviour (mutual support) and team satisfaction were measured creating a questionnaire by using the preceding research.

The responses were recorded on five- point Likert-type scales with "strongly disagree" to "strongly agree". Questions were in Japanese and English. Before distributing the questionnaire, all items were translated to the Sinhala language.

Four items were adapted from Van Der Vegt and Van De Vliert (2000) ${ }^{[81]}$ and Cammann, Fichman, Jenkins and Klesh's (1983) ${ }^{[8]}$ to evaluate Team satisfaction as "I am satisfied with my present colleagues", "I am pleased with my colleagues' the way of work", "I am very satisfied with work in this team" and "I am satisfied with the friendliness of my team members". Cronbach's alpha value is .77.

Mutual support was assessed by using five items which were taken from Morita (2008) ${ }^{[52]}$ and Champion et al. (1993) [9]. "If I got into difficulty at work, my section members would help me". "I help my workmates when they have work problems on the line" "If any problem occurred on my work, it could be resolved by discussing with my colleagues", "On my day off, when I finish my daily work, I may help someone who is not finished" and "Members of my team share information with other team members about our work". Cronbach's alpha value is .69 .

Common goal was measured by using three items, "I know our team's final goal" "In my team, we are jointly responsible for workplace results" and "In my team, we have a clear goal to be achieved as a team" (Suzuki, 2011; Morita, 2008) ${ }^{[75,52]}$. These were translated from Japanese to Sinhala. Cronbach's alpha value is .72.

Multi-skills were assessed with three items which were taken from a questionnaire which has been used to evaluate teamwork in Japan, the United Kingdom and China by Morita (2008) ${ }^{[52]}$. Those items are "I can perform more than one task in the team", "Team members of my team know each other's job" and "I can cover absentee work in my team".

Task interdependence was evaluated with five items such as "I have to obtain information and advice from my colleagues to complete my work", "I have to depend on my colleagues for the completion of my work", "In order to complete their work, my colleagues have to obtain information and advice from me", "I need to collaborate with my colleagues to perform my job well" and "Team members frequently have to coordinate their effort with each other" (Van der Vegt \& Janssen, 2003) ${ }^{[82]}$.

\section{Analysing methods}

The IBM SPSS statistic and Amos 23 version are used to carry out statistical analysis.

Firstly, Exploratory Factor Analysis (EFA) was performed by using Unweighted Least Squares through the SPSS FACTOR Analysis to evaluate the validity of items which were used to measure multi-skills, common goal, task interdependence and mutual support factors since some items have not been checked against the validity in the previous research, for instance, items which were used by Morita (2008) ${ }^{[52]}$ to evaluate multi-skills. As an extraction method, Promax rotation is used. This is because, when there is not any strong theoretical background to prove no correlation between factors, it is better to use an oblique rotation method such as Promax (Yamagiwa \& Hattori, 2016; Field, 2013) ${ }^{[90,19]}$. Here, based on the theoretical explanations, it can be assumed that there are relationships between multi-skills, a common goal, task interdependence and mutual support factors. For instance, Chen et al. (2009) ${ }^{[12]}$ and Van der Vegt and Janssen (2003) ${ }^{[82]}$ have proved that correlation between common goal and task interdependence, statistically.

Then, correlations of variables were calculated. Finally, in order to verify the seven hypotheses of this paper, path analysis was performed through the structural equation modelling.

\section{Results \\ Results on Statistical Analysis}

Exploratory factor analysis (EFA) was performed by using maximum likelihood extraction with promax rotation through the SPSS FACTOR Analysis on 16 items. Based on factor analysis results, Kaiser-Mayer-Olkin (KMO value) measures of samples adequacy was .780 and determined factorability, since it exceed the minimum value of 0.5 (Field, 2013) ${ }^{[19]}$. The $\chi^{2}$ test statics of Bartlett's test of sphericity was significant at $\mathrm{p}<.001$, which indicated that all correlations were significantly different from zero.

Factors in which the Eigen value is higher than 1.0 (Field, 2013) ${ }^{[19]}$ were extracted. Four factors were extracted and altogether accounted for 63 percent of the variance in responses. Factors 1 to 4 were named as mutual support, common goal, multi-skills and task interdependence. Team satisfaction is calculated as a composite variable.

\section{Correlations of Variables}

Next, correlations between team satisfaction and factors (team characteristics) which were identified though the factor analysis were calculated. Results (see Table 1) revealed that there are correlations between the team characteristics and team satisfaction, in which, comparatively, the relationship between common goal and team satisfaction is higher than other factors, $\mathrm{r}=0.53$, $p<0.01$. Also, mutual support was related with team satisfaction $(\mathrm{r}=0.42, \quad p<0.01)$ and multi-skills was significantly related with team satisfaction $(\mathrm{r}=0.28, p<0.01)$. Further, mutual support was significantly related with the other characteristics of the team. Typically, the correlation value between mutual support and common goal is $(\mathrm{r}=0.56$, $p<0.01$ ), mutual support and task interdependency is 
$(\mathrm{r}=0.49, p<0.01)$ and mutual support and multi-skills is $(\mathrm{r}=0.56, p<0.01)$. As well, relationships between common goal and multi-skills $(\mathrm{r}=0.41, \quad p<0.01)$ and task interdependence and multi-skills $(\mathrm{r}=0.34 p<0.01)$ were significant.

Table 1: Correlation Values

\begin{tabular}{|c|c|c|c|c|c|}
\hline \multirow{2}{*}{ Variables } & \multicolumn{5}{|c|}{ Variables } \\
\cline { 2 - 6 } & 1 & 2 & 3 & 4 & 5 \\
\hline $1 . \quad$ Team Satisfaction & 1 & & & & \\
\hline 2. Mutual Support & $.42^{* *}$ & 1 & & & \\
\hline 3. Common Goal & $.53^{* *}$ & $.56^{* *}$ & 1 & & \\
\hline 4. Task interdependence & .10 & $.49^{* *}$ & $.17 *$ & 1 & \\
\hline 5. Multi-skills & $.28^{* *}$ & $.56^{* *}$ & $.41^{* *}$ & $.34 * *$ & 1 \\
\hline
\end{tabular}

$* p<.05, * * p<.01$

Source: The Analysis Results.

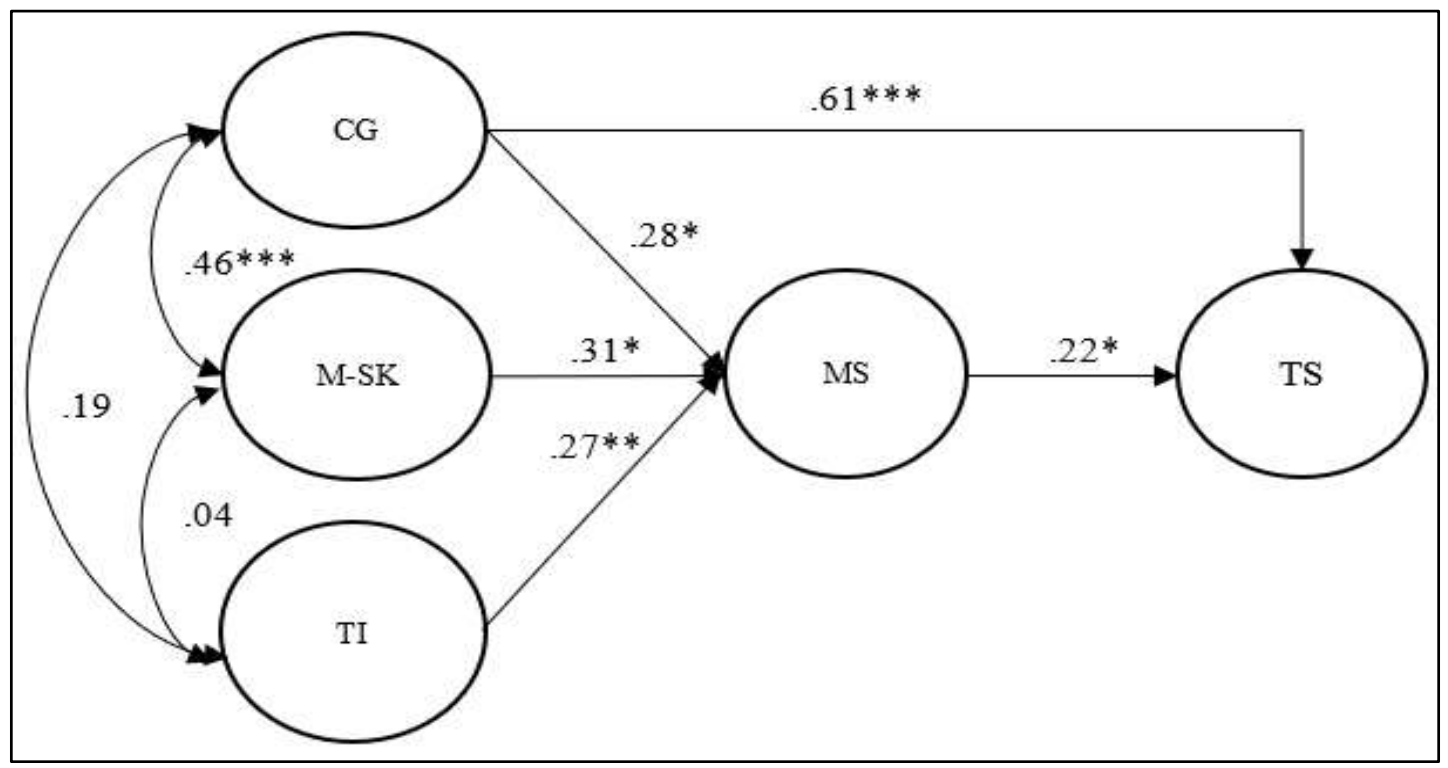

Note: CG- Common Goal, M-SK- Multi-skills, TI- Task Interdependence, MS- Mutual Support and TS-Team Satisfaction Source: The Analysis Results.

$* p<.05, * * * p<.001$

Fig 2: the Estimated Structural Model

\section{Causal Relationship of Variables}

The Structural equation model analysis was conducted to evaluate the relationship between team characteristics and team satisfaction.

The following goodness-of-fit indices provide information about the overall fit of the empirical data to the hypothesized model. Regarding Model 1, in which were included all variables (as in Figure 1) the overall chi-square was statistically significant ( $\left.\mathrm{X}^{2} 178.58 ; \mathrm{df} .=94 ; p<.001\right)$, the CMIN/DF was 1.9 , The GFI was .881, AGFI was .828, IFI was .870 , CFI was .864 and RMSEA is .07. However, the direct effect of multi-skills and task interdependence to the team satisfaction could not be seen in Model 1 since causal relationships of them were not significant at 5 per cent level. Therefore, the structural equation model analysis was conducted again excluding direct effect of multi-skills and task interdependence to the team satisfaction. Regarding Model 2 (see Figure 2) the overall chi-square was statistically significant $\left(X^{2} 178.95 ;\right.$ df. $\left.=96 ; p<.001\right)$, the CMIN/DF was 1.86 , The GFI was .881, AGFI was .831, IFI was .872, CFI was .867 and RMSEA is .07.

In general, a conceptualized model is accepted as a wellfitting one, when the chi-square is statistically not significant, RMSEA $<0.05$ and other fit indices; GFI, AGFI, IFI and CFI are 0.90 or greater (Oshio, 2017; Bentler \& Bonett, 1980) ${ }^{[58,5]}$. However, there are studies which have pointed out that fit indices; GFI, AGFI, IFI and CFI are 0.80 or greater (Lantz, Hansen \& Antoni, 2015; Hwang, Wen \& Chen, 2010) [43] and RMSEA $<0.08$ (Yuan, Chan, Marcoulides \& Bentler, 2016; Chen et al., 2009) ${ }^{[92,12]}$ and CMIN/DF<3 (Iacobucci, 2010) ${ }^{[21]}$ are sufficient to consider any model as acceptable. Therefore, based on these explanations, Model 1 and 2 can be considered as acceptable models to explain the causal relationship of team characteristics and team satisfaction. However, Model 2 (see Figure 2) is taken as the estimated structural model since some fit indicators slightly higher than Model 1.

\section{Test of Hypothesis}

The results of the hypotheses testing are summarized in Table 2 .

According to structural coefficients which have been shown in Figure 2, common goal has a positive effect on mutual support $(\beta=0.28, p<.05)$ thus supporting H1. The multiskills and the task interdependence have significantly positive effects on the mutual support $(\beta=0.31, p<.05$ and $\beta=0.27, p<.01$, respectively) thus $\mathrm{H} 2$ and $\mathrm{H} 3$ are supported. The common goal has a significantly positive effect on the team satisfaction $(\beta=0.61, p<.001)$, and $\mathrm{H} 4$ is supported. Mutual support has a significantly positive effect on the team satisfaction $(\beta=0.22, p<.05)$ supporting $\mathrm{H} 7$. However, H5 and H6 are not supported (see Table 2) since 
the path coefficients in Model 1 regarding causal linkage between the team satisfaction and both variables are not significant at the 5 per cent level. Those values are "Multiskills $\rightarrow$ Team Satisfaction" $(\beta=-0.05, \mathrm{p}>.05)$ are "Task
Interdependence $\rightarrow$ Team Satisfaction" $(\beta=-0.04, \mathrm{p}>.05)$. Further, even though it was not hypothesized, a significant positive correlated effect between the common goal and multi-skills can be seen in Figure $2(\gamma=0.46, p<0.001)$.

Table 2: Summary of Hypothesis Testing Results

\begin{tabular}{|c|c|c|}
\hline Hypothesises & & Testing results \\
\hline H1 & Common Goal $\rightarrow$ Mutual Support & Supported \\
\hline H2 & Multi-skills $\rightarrow$ Mutual Support & Supported \\
\hline H3 & Task Interdependence $\rightarrow$ Mutual Support & Supported \\
\hline H4 & Common Goal $\rightarrow$ Team Satisfaction & Supported \\
\hline H5 & Multi-skills $\rightarrow$ Team Satisfaction & Not supported \\
\hline H6 & Task Interdependence $\rightarrow$ Team Satisfaction & Not supported \\
\hline H7 & Mutual Support $\rightarrow$ Team Satisfaction & Supported \\
\hline
\end{tabular}

Source: The Analysis Results.

\section{Discussions}

This study was designed to determine the relationship between the team characteristics and the team satisfaction of the manufacturing workers in Sri Lanka. The empirical survey was carried out to measure team members' perception of a common goal, multi-skills capability, subjective task interdependence, supportive behaviour and satisfaction of team.

As mentioned in the introduction, there is a lack of previous investigations which have been conducted to examine relationships between team characteristics and team satisfaction integrating all team characteristics: mutual support, a common goal, multi-skills and task interdependence, which have been subjected here, to one model. To deal with this issue, CFA was set up developing a conceptual framework (see Figure 1) presenting all the predictable relations.

The survey findings revealed that there is a relationship between team characteristics and team satisfaction. However, a hypothesis of multi-skills (H5) and a hypothesis of task interdependence (H6) have not been confirmed. Therefore, the empirical finding is consistent with Morris and Venkatesh (2010) ${ }^{[54]}$ and inconsistent with Costen \& Salazar (2011) ${ }^{[15]}$ because team satisfaction and multi-skills has not presented a direct relationship between them. Typically, the factory provides facilities to develop multiskills to the employees under the multi-skill development program. However, having various kinds of knowledge is not a reason or work condition which creates a direct effect for the team satisfaction as discussed by the previous studies (Potnuru et al., 2018; Felstead et al., 2015; French, Du Plessis \& Scrooby, 2011; Ketchum \& Trist, 1992) [62, 17, 20, ${ }^{35]}$. Further, the findings of task interdependence supported the empirical investigations of Champion et al. (1996) ${ }^{[10]}$ and Champion et al. (1993) ${ }^{[9]}$ and contradicted with Van de Vliert et al. (2001) ${ }^{[80]}$ and Van Der Vegt \& Van De Vliert (2000) ${ }^{[81]}$ since there is not a direct relationship between team satisfaction and task interdependence.

Meanwhile, the $\mathrm{H} 4$ and the $\mathrm{H} 7$ also evaluated the direct relationship between common goal, mutual support and team satisfaction. The path coefficient result revealed that employees' awareness of a common goal has created the greatest significant positive effect $(\beta=0.61, p<.001)$ on the team satisfaction. This result confirms the previous discussion regarding relationship between common goal and team satisfaction (Stark \& Bierly III 2009; Van de Vliert et al., 2001; Champion et al., 1996) ${ }^{[73,80,10]}$. Stark and Bierly III (2009) ${ }^{[73]}$ and Champion et al. (1996) ${ }^{[10]}$ have pointed out that equally shared responsibilities is the reason behind the relationship. Another reason can be assumed regarding the Sri Lankan context. Yousaf, Latif, Aslam and Saddiqui (2014) ${ }^{[91]}$ have argued that a developing country's workers are willing to have more extrinsic benefits than intrinsic. This argument is applicable to a Sri Lankan context too, as a developing country, since Chandrakunara and Sparrow (2004) say, Sri Lankan workers are more extrinsic reward oriented than intrinsic. Sri Lankan workers, when making a decision on their work, for example make a decision to leave from the present job, considerations on financial benefits get priority over other reasons. For instance, Pushpakumari (2008) ${ }^{[64]}$ has revealed that 56 per cent of workers have left due to financial benefits problems. Further, the study also provides sufficient evidence to prove this situation, because about 63 per cent of workers say that inadequate salary payment was a reason to leave from the previous job. This extrinsic benefit oriented workers' behaviour is useful to explain the direct relationship between common goal and team satisfaction in the Sri Lankan context. In the factory, the workers' production target can be interpreted as their common goal. The accomplishment of a team's goal, that is assigned production target, is considered to the incentive calculations. In other words, when completing the production target, the production incentive is applicable. That is, achievement of the target (common goal) as a team increase their salaries. Hence, it can be assumed that, the employees' real goal is to earn more incentives through the accomplishment of a common goal. Thus, workers have more awareness about the existence of common goal since Parker, McAdams and Zielinski (2001) ${ }^{[60]}$ and Leana III and Van Buren, (1999) ${ }^{[44]}$ have insisted that team-based compensation policies encourage the intension of team members on a common goal. Accordingly, it is able to be assumed that the earning incentives on the team-based compensation policies mediates the effect of team members' sense of a common goal on team satisfaction. However, further research is of course needed to determine the validity of these explanations.

Consistent with previous empirical findings regarding the relationship between mutual support and a common goal (Suzuki, 2013; Chen et al., 2009) [76, 12] and task interdependence (Hu \& Liden, 2015; 2011; Suzuki, 2013; Van der Vegt \& Van de Vliert, 2005) ${ }^{[28,27,76,83]}$, the present study confirmed that a common goal, multi-skills and task interdependence ( $\mathrm{H} 1, \mathrm{H} 2$ and $\mathrm{H} 3)$ play substantial roles in the enhancement of mutual support among team members. In other words, a common goal, multi-skills and task interdependence make the necessary requirements to arrange a work place that is favourable to perform supportive 
activities among team members; mutual support is thus promoted by them.

The present study also confirmed that the mutual support feature makes a positive significant effect on the team satisfaction. The path coefficient value of mutual support presents enough evidence to testify the H7. In turn, the study results corroborate findings of prior studies of Schreurs et al., (2015) [69] and Champion et al., (1996) [10] which reported the relationship between mutual support and team satisfaction. However, not only the direct effect, but reciprocal supportive behaviour at the team also creates the mediating effects to the relationship between team satisfaction and other team characteristics; common goal, multi-skills and task interdependence, which has been ignored by most of the previous research. Typically, the evident paths: "common goal $\rightarrow$ mutual support $\rightarrow$ team satisfaction, multi-skills $\rightarrow$ mutual support $\rightarrow$ team satisfaction and task interdependence $\rightarrow$ mutual support $\rightarrow$ team satisfaction" which appear in the estimated model (see Figure 2) explain this relationship. Accordingly, the study proved the mechanism of mutual support (behavioural level team characteristic) in the relationship between workers' level team characteristics and team satisfaction. As well, the evident path; multi-skills $\rightarrow$ mutual support $\rightarrow$ team satisfaction, reveal the importance of the multi-skills training and development for the team functioning and effectiveness, which have not been paid a lack of attention in the literature.

In the Sri Lankan context, Pathirage et al. (2012) ${ }^{[61]}$ have reported that management support is an essential element to improve team effectiveness and the results of the study provide a mechanism to explain the relationship further. This is because, the findings of the study touch on, but not statistically, the importance of the management practices: team-based goals setting, arranging training and development to expand the task-related skills of workers and designing work flow ensuring interconnectedness, which encourage the team characteristics: common goals, multiskills and task interdependence, as the previous research (Bratton \& Gold, 2017; Kirkman \& Rosen, 1999) ${ }^{[6,37]}$ has also been insisted. Subsequently these factors influence the supportive behaviour and then improve the team satisfaction as a means of team effectiveness (Breuer et al., 2016; Cohen \& Bailey, 1997) ${ }^{[14]}$. Thus, managers are able to provide assistant to work teams by practicing such a way of management in their work places.

\section{Conclusion}

The study investigated the team satisfaction by constructing a model which included common characteristics of a work team: mutual support, a common goal, multi-skills and task interdependence. There are some previous research which has concerned the relationship between team characteristics and team satisfaction. However, it is difficult to find previous research which has embedded all characteristics of the team which were taken into account by the study, into one model. The structural relationships between all variables were evaluated using quantitative data which was obtained from the manufacturing organization in Sri Lanka.

The study verified that a common goal, multi-skills and task interdependence indirectly affect team satisfaction through the mediation of mutual support. That means, a common goal, multi-skills and task interdependence may strengthen mutual support, further leading to enhance team members' satisfaction. Further, the direct relationship between team satisfaction and common goal confirmed the previous research, too. Finally, the present study results theoretically contribute to the understanding of the rudimentary process in the relationship between characteristics of team and team satisfaction.

However, there are points to be clarified in future research. Future research may investigate the effect of the earning incentives on the team-based compensation policies as a moderator on the relationship between a common goal and team satisfaction. In addition, the sample size should be increased in the future studies because some fit indices which are controlled by the sample size (Iacobucci, 2010; Marsh, Hau \& Wen, 2004) [31] were below the generally accepted level.

\section{References}

1. Allwood JM, Lee WL. The impact of job rotation on problem solving skills. International Journal of Production Research 2004;42(5):865-881.

2. Appelbaum E, Bailey $\mathrm{T}$, Berg PB, Kalleberg AL, Bailey TA. Manufacturing advantage: Why highperformance work systems pay off. London: Cornell University Press 2000.

3. Bamberger P. Employee help-seeking: Antecedents, consequences and new insights for future research. In Research in personnel and human resources management 2009;2849-98.

4. Barczak G, Wilemon D. Factors influencing product development team satisfaction. European Journal of Innovation Management. 2001;4(1):32-36.

5. Bentler PM, Bonett DG. Significance tests and goodness of fit in the analysis of covariance structures. Psychological bulletin 1980;88(3):588-606.

6. Bratton J, Gold J. Human resource management: theory and practice. London: Palgrave 2017.

7. Breuer C, Hüffmeier J, Hertel G. Does trust matter more in virtual teams? A meta-analysis of trust and team effectiveness considering vitality and documentation as moderators. Journal of Applied Psychology 2016;101(8):1151-1177.

8. Cammann C, Fichman M, Jenkins GD, Klesh J. Michigan organizational assessment questionnaire. In S. E. Seashore, E. E. Lawler, P. H. Mirvis, \& C. Camman (Eds.), Assessing Organizational Change: A Guide to Methods, Measures, and Practices. New York: WileyInter science 1983, 71-138

9. Champion MA, Medsker GJ, Higgs AC. Relations between work group characteristics and effectiveness: Implications for designing effective work groups. Personnel psychology 1993;46(4):823-847.

10. Champion MA, Papper EM, Medsher G. Relations between work-team characteristics and effectiveness: A replication and extension. Personnel Psychology, 1996;49(2):429-453.

11. Chandrakumara A, Sparrow P. Work orientation as an element of national culture and its impact on HRM policy-practice design choices: Lessons from Sri Lanka. International Journal of Manpower 2004;25(6):564-589.

12. Chen CHV, Tang YY, Wang SJ. Interdependence and organizational citizenship behaviour: Exploring the mediating effect of group cohesion in multilevel analysis. The Journal of Psychology, 2009;143(6):625640 . 
13. Clancy CM, Tornberg DN. Team STEPPS: assuring optimal teamwork in clinical settings. American Journal of Medical Quality 2007;22(3):214-217.

14. Cohen SG, Bailey DE. What makes teams work: Group effectiveness research from the shop floor to the executive suite. Journal of management 1997;23(3):239-290.

15. Costen WM, Salazar J. The impact of training and development on employee job satisfaction, loyalty, and intent to stay in the lodging industry. Journal of Human Resources in Hospitality \& Tourism 2011;10(3):273284.

16. Courtright SH, Thurgood GR, Stewart GL, Pierotti AJ. Structural interdependence in teams: An integrative framework and meta-analysis. Journal of Applied Psychology 2015;100(6):1825-1847.

17. Felstead A, Gallie D, Green F, Inanc H. Fits, misfits and interactions: Learning at work, job satisfaction and job - related well - being. Human Resource Management Journal 2015;25(3):294-310.

18. Fenlason KJ, Beehr TA. Social support and occupational stress: Effects of talking to others. Journal of Organizational Behaviour 1994;15(2):157-175.

19. Field A. Discovering statistics using IBM SPSS statistics. Los Angeles: Sage 2013.

20. French H, Du Plessis E, Scrooby B. The emotional well-being of the nurse within the multi-skill setting. Health SA Gesondheid 2011;16(1):1-9. doi:10.4102/hsag.16i1.553.

21. Gallie D, Zhou Y, Felstead A, Green F. Teamwork, skill development and employee welfare. British Journal of Industrial Relations 2012;50(1):23-46.

22. Gittell JH. Relational coordination: Guidelines for theory, measurement and analysis. Waltham, MA: Brandeis University 2011.

23. Gonzalez-Mulé E, DeGeest DS, McCormick BW, Seong JY, Brown KG. Can we get some cooperation around here? The mediating role of group norms on the relationship between team personality and individual helping behaviours. Journal of Applied Psychology, 2014;99(5):988-999.

24. Greenwood I, Randle H. Team-working, Restructuring and Skills in UK and Sweden. European journal of industrial relations 2007;13(3):361-377.

25. George JM, Jones GR. Organizational spontaneity in context. Human performance 1997;10(2):153-170.

26. Hertel G, Konradt U, Orlikowski B. Managing distance by interdependence: Goal setting, task interdependence, and team-based rewards in virtual teams. European Journal of work and organizational psychology, 2004;13(1):1-28.

27. Hu J, Liden RC. Antecedents of team potency and team effectiveness: An examination of goal and process clarity and servant leadership. Journal of Applied psychology 2011;96(4):851-862.

28. Hu J, Liden RC. Making a difference in the teamwork: Linking team prosocial motivation to team processes and effectiveness. Academy of Management Journal, 2015;58(4):1102-1127.

29. Hüffmeier J, Hertel G. Many cheers make light the work: how social support triggers process gains in teams. Journal of Managerial Psychology, 2011;26(3):185-204.
30. Hwang YD, Wen YF, Chen MC. A study on the relationship between the PDSA cycle of green purchasing and the performance of the SCOR model. Total Quality Management 2010;21(12):1261-1278.

31. Iacobucci D. Structural equations modelling: Fit indices, sample size, and advanced topics. Journal of consumer psychology 2010;20(1):90-98.

32. Jayawardana A, O'Donnell M. Devolution, job enrichment and workplace performance in Sri Lanka's garment industry. The Economic and Labour Relations Review 2009;19(2):107-122.

33. Kalleberg AL, Nesheim T, Olsen KM. Is participation good or bad for workers? Effects of autonomy, consultation and teamwork on stress among workers in Norway. Acta Sociologica 2009;5(22):99-116.

34. Katzenbach JR, Smith DK. The wisdoms of teams. Boston: Harvard Business School press 1993.

35. Ketchum L, Trist E. All teams are not created equal: How employee empowerment really works. USA: Sage Publications 1992.

36. Kiggundu MN. Task interdependence and job design: Test of a theory. Organizational behaviour and human performance 1983;31(2):145-172.

37. Kirkman BL, Rosen B. Beyond self-management: Antecedents and consequences of team empowerment. Academy of Management journal 1999;42(1):58-74.

38. Klein JA. Maintaining expertise in multi-skilled teams. In Beyerlein, M.M. \& Johnson, D.A. (eds.), Advances in Interdisciplinary Studies of Work Teams Greenwich, Connecticut: JAI Press 1994, 145-166.

39. Kozlowski SWJ, Bell BS. Work groups and teams in organizations: Review update. In N. Schmitt \& S. Highhouse (Eds.), Handbook of psychology: Industrial and organizational psychology Hoboken, NJ: Wiley. 2013;12(2 ed):412-469

40. Kulasooriya DMA, Chalapathi RS. Lean manufacturing maturity assessment in garment industries-A case study from Sri Lanka. ACADEMICIA: An International Multidisciplinary Research Journal 2014;4(5):193-217.

41. Kumar K, van Fenema PC, Von Glinow MA. Offshoring and the global distribution of work: Implications for task interdependence theory and practice. Journal of International Business Studies, 2009;40(4):642-667.

42. Lanarolle G, Ratnayaka V. Cellular Manufacturing and Teamwork Concepts in Garment Manufacturing. Journal of Business and Management, 2014;16(6):8193.

43. Lantz A, Hansen N, Antoni C. Participative work design in lean production: A strategy for dissolving the paradox between standardized work and team proactivity by stimulating team learning? Journal of Workplace Learning 2015;27(1):19-33.

44. Leana III CR, Van Buren HJ. Organizational social capital and employment practices. Academy of management review, 1999;24(3):538-555.

45. Lunenburg FC. Goal-setting theory of motivation. International journal of management, business, and administration 2011;15(1):1-6.

46. Mair A. The Introduction of Teamwork at Rover Group's Stamping. In Castillod J.J, Stewart, P., Durand, J.P. \& Castillo, J.J. (eds.) Teamwork in the Automobile Industry: Radical Change or Passing Fashion? New York: Palgrave McMillan 2007, 254-286. 
47. Marsh HW, Hau KT, Wen Z. In search of golden rules: Comment on hypothesis-testing approaches to setting cut-off values for fit indexes and dangers in overgeneralizing $\mathrm{Hu}$ and Bentler's (1999) findings. Structural equation modelling 2004;11(3):320-341.

48. Mathieu J, Maynard MT, Rapp T, Gilson L. Team effectiveness 1997-2007: A review of recent advancements and a glimpse into the future. Journal of management, 2008;34(3):410-476.

49. Mayfield CO, Tombaugh JR, Lee M. Psychological collectivism and team effectiveness: moderating effects of trust and psychological safety. Journal of Organizational Culture, Communications \& Conflict, 2016;20(1):78-94.

50. McIntyre RM, Salas E. Measuring and Managing for Team Performance: Lessons from Complex Environment. In Guzzo, R. A., \& Salas, E. (eds). Team effectiveness and decision making in organizations San Francisco: Jossy-Bass 1995, 9-48.

51. Morgeson FP, Humphrey SE. Job and team design: Toward a more integrative conceptualization of work design. Research in personnel and human resources management 2008;27:39-91.

52. Morita M. Chīmu sagyō hōshiki no tenkai [Development of Teamworking]. Japan: Chikurashōbo 2008.

53. Morita M, Wanninayaka M. Surirankani okeru josei rōdō no genjō: surirankade no chimusagyō dōnyu ni mukete yobi kōsatu [The current situation of Sri Lankan female workers : as a preliminary study for the introduction of Sri Lankan teamworking]. kansaidaigaku shakaigakubukiyō. 2016;48(1):139-152.

54. Morris MG, Venkatesh V. Job characteristics and job satisfaction: understanding the role of enterprise resource planning system implementation. Mis Quarterly 2010;34(1):143-162.

55. Neirotti P. Work intensification and employee involvement in lean production: new light on a classic dilemma. The International Journal of Human Resource Management2018, 1-26. Retrieved from https://doi.org/10.1080/09585192.2018.1424016.

56. Ohno T. Toyota Seisanhōsiki, Datsukibō no Keieio Mezashite [Toyota Production System: Beyond LangeScale Production]. Japan: Daiyamondosha 1978.

57. Okubayasi K. Hataraki Yasui Sosiki [Organizations which Easy to Work]. Japan: Morimoto 2002.

58. Oshio A. Hajimeteno Kyōbunsankōzōbunseki (Dai2han) - Amosniyorupasukaiseki, Tokyōtoshō, Japan 2017.

59. Owens BP, Hekman DR. How does leader humility influence team performance? Exploring the mechanisms of contagion and collective promotion focus. Academy of Management Journal, 2016;59(3):1088-1111.

60. Parker GM, Zielinski D, McAdams J. Rewarding teams: Lessons from the trenches. San Francisco: Jossey-Bass Inc. 2001

61. Pathirage YD, Jayawardena LNAC, Rajapaksha TN. Impact of Management Support for Team Performance: A Sri Lankan Case study in Apparel Industry. Tropical Agricultural Research 2012;23(3):228-236.

62. Potnuru RKG, Sahoo CK, Sharma R. Team building, employee empowerment and employee competencies: Moderating role of organizational learning culture.
European Journal of Training and Development. Retrieved from https://doi.org/10.1108/EJTD-08-20180086. 2018.

63. Procter S, Mueller F. Teamworking: strategy, structure, systems and culture. In Procter, S. and F. Mueller (eds.), Teamworking London: Macmillan 2000, 3-24.

64. Pushpakumari MD. The impact of job satisfaction on job performance: An empirical analysis. Meijo ronshu, 2008;9(1):89-105.

65. Ramamoorthy N, Flood PC. Individualism/collectivism, perceived task interdependence and teamwork attitudes among Irish blue-collar employees: a test of the main and moderating effects? Human Relations, 2004;57(3):347-366.

66. Saavedra R, Earley PC, Van Dyne L. Complex interdependence in task-performing groups. Journal of applied psychology 1993;78(1):61.72.

67. Salas E, Shuffler ML, Thayer AL, Bedwell WL, Lazzara EH. Understanding and improving teamwork in organizations: a scientifically based practical guide. Human Resource Management 2015;54(4):599-622.

68. Sapada AFA, Modding HB, Gani A, Nujum S. The effect of organizational culture and work ethics on job satisfaction and employees performance. The International Journal of Engineering and Science (IJES). 2018;6(12):28-36.

69. Schreurs B, Guenter H, van Emmerik IH, Notelaers G, Schumacher D. Pay level satisfaction and employee outcomes: the moderating effect of autonomy and support climates. The International Journal of Human Resource Management 2015;26(12):1523-1546.

70. Silva N, Perera HSC, Samarasinghe D. Factors affecting successful implementation of lean manufacturing tools and techniques in the apparel industry in Sri Lanka 2011 Retrieved from

71. https://www.researchgate.net/profile/Chandana_Perera2 /publication/228233271_Factors_Affecting_Successful _Implementation_of_Lean_Manufacturing_Tools_and_ Techniques_in_the_Apparel_Industry_in_Sri_Lanka/lin ks/5825efe208aeebc4f8a1e272.pdf.

72. Somech A, Desivilya HS, Lidogoster H. Team conflict management and team effectiveness: The effects of task interdependence and team identification. Journal of Organizational Behaviour, 2009;30(3):359-378.

73. Stark EM, Bierly III PE. An analysis of predictors of team satisfaction in product development teams with differing levels of virtualness. $R \& d$ Management, 2009;39(5):461-472.

74. Strubler DC, York KM. An exploratory study of the team characteristics model using organizational teams. Small Group Research, 2007;38(6):670-695.

75. Suzuki R. Shokuba ni okeru Sōikufū no Manejimento: Kakawariau Shūdan no Kenkyūkaihatsusha no Sinshutekikōdoe no Eikyō ni kansuru Kurosureberu Bunseki. Sosikikagaku [Management of Proactive Behaviour at Workplace: The Effects of Task and Goal Interdependence and Group Cohesiveness at the Group Level], 2011;44(4):26-38.

76. Suzuki R. Kakawariau Shokuba no Manejimento [Management of Workplace Relationship]. Japan: Yūhikaku 2013.

77. Trist EL. The Evolution of Socio-technical Systems: A Conceptual Framework and an Action Research 
Program (Issue 2 of Occasional paper). Ontario Quality of Working Life Centre 1981.

78. Trist EL, Higgin GW, Murray H, Pollock AB. Organizational choice. New York: Garland Publishing. Reprinted (First published 1963) 1987.

79. Ullah USE, Park DS. Shared leadership and team effectiveness: Moderating effects of task interdependence. African Journal of Business Management 2013;7(40):4206-4220.

80. Van de Vegt GS, Emans BJ, Van de Vliert E. Patterns of interdependence in work teams: A two-level investigation of the relations with job and team satisfaction. Personnel Psychology 2001;54(1):51-69.

81. Van Der Vegt G, Emans B, Van De Vliert E. Team members' affective responses to patterns of intragroup interdependence and job complexity. Journal of management 2000;26(4):633-655.

82. Van der Vegt GS, Janssen O. Joint impact of interdependence and group diversity on innovation. Journal of management 2003;29(5):729-751.

83. Van der Vegt GS, Van de Vliert E. Effects of perceived skill dissimilarity and task interdependence on helping in work teams. Journal of management 2005;31(1):7389.

84. Wanninayaka M. Nature of Teamwork Practices in the Manufacturing Factories of Sri Lanka: A case of garment manufacturing factories. Ningenkagaku (Human Science) 2015;83:39-58.

85. Weingart LR, Weldon E. Processes that mediate the relationship between a group goal and group member performance. Human Performance 1991;4(1):33-54.

86. Wellins RS, Byham WC, Wilson JM. Empowered teams: Creating self-directed work groups that improve quality, productivity, and participation. San Francisco: Jossey-Bass 1991.

87. Wickramasinghe D, Wickramasinghe V. Perceived organisational support, job involvement and turnover intention in lean production in Sri Lanka. The International Journal of Advanced Manufacturing Technology 2011;55(5-8):817-830.

88. Womack JP, Jones DT, Roos D. The machine change the world: based on Massachusetts Institute of Technology 5- million dollar 5- year study on the future of the Automobile. New York, Free Press 1990.

89. Wong A, Tjosvold D, Liu C. Innovation by teams in Shanghai, China: cooperative goals for group confidence and persistence. British Journal of Management 2009;20(2):238-251.

90. Yamagiwa Y, Hattori T. Bunkeinotameno SPSS detakaiseki [SPSS Data Analysis for Liberal Students]. Japan: Nakanishiya 2016.

91. Yousaf S, Latif M, Aslam S, Saddiqui A. Impact of financial and non-financial rewards on employee motivation. Middle-East journal of scientific research, 2014;21(10):1776-1786.

92. Yuan KH, Chan W, Marcoulides GA, Bentler PM. Assessing structural equation models by equivalence testing with adjusted fit indexes. Structural Equation Modelling: A Multidisciplinary Journal 2016;23(3):319-330. 